\title{
Is intramedullary nailing applicable for distal tibial fractures with ankle joint extension?
}

\author{
Ayak bileği eklemine uzanan distal tibia kırıklarında intramedüller çivi uygulanabilir mi?
}

Ozan Beytemür, MD., Cem Albay, MD., Oktay Adanır, MD., Serdar Yüksel, MD., Mehmet Akif Güleç, MD.

Department of Orthopedics and Traumatology, Bağcılar Training and Research Hospital, İstanbul, Turkey

\begin{abstract}
Objectives: This study aims to evaluate the functional and radiographic results and treatment complications of AO/OTA (Arbeitsgemeinschaft fur Osteosynthesefragen/ Orthopaedic Trauma Association) type 43C1 and C2 fractures treated with intramedullary nailing.

Patients and methods: We retrospectively evaluated 35 AO/OTA type $43 \mathrm{C} 1$ and $\mathrm{C} 2$ patients (26 males, 9 females; mean age $39.8 \pm 16.9$ years; range 19 to 82 years) treated with intramedullary nailing. Two interfragmentary screws out of nail were applied in 10 patients $(29 \%)$, while one interfragmentary screw out of nail was applied in 17 patients $(49 \%)$. Intramedullary nailing was applied in eight patients $(23 \%)$ without external screws. Fracture union, union time, alignment problems, and complications were evaluated. Clinical evaluation of patients was conducted using the Olerud and Molander score and by measuring the ankle joint range of motion.
\end{abstract}

Results: Union was achieved in all 35 patients. Mean union time was $16.5 \pm 2.8$ weeks (range 12 to 24 weeks) and mean Olerud and Molander score was $88 \pm 8.24$. Varus deformity was detected in one patient, valgus deformity was detected in two patients, and rotation deformity was detected in one patient. Superficial infection was detected in three patients (9\%). Deep infection was not detected in any patient.

Conclusion: Intramedullary nailing is not contraindicated for simple intra-articular distal tibial fractures. In these fractures, intramedullary nailing performed in accordance with its technique, with an additional percutaneous screw if necessary, is a successful treatment option with high fracture union rates, high functional results, and low complication rates.

Keywords: Fracture fixation; intra-articular fractures; intramedullary; tibial fractures.

\section{ÖZ}

Amaç: Bu çalışmada intramedüller çivi ile tedavi edilen AO/OTA (Arbeitsgemeinschaft fur Osteosynthesefragen/ Orthopaedic Trauma Association) $43 \mathrm{C} 1$ ve $\mathrm{C} 2$ tipi kırıkların fonksiyonel ve radyolojik sonuçları ile tedavi komplikasyonları değerlendirildi.

Hastalar ve yöntemler: İntramedüller çivi ile tedavi edilen 35 AO/OTA tip $43 \mathrm{C} 1$ ve $\mathrm{C} 2$ hasta (26 erkek, 9 kadın; ort. yaş $39.8 \pm 16.9$ yıl; dağılım 19-82 yıl) retrospektif olarak değerlendirildi. On hastada (\%29) çivi dışı interfragmanter ilave iki vida uygulanırken 17 hastada (\%49) çivi dış1 interfragmanter ilave bir vida uygulandı. Sekiz hastada (\%23) çivi dışı interfragmanter ilave vida uygulanmadı. Kırığın kaynama durumu, kaynama süresi, dizilim problemleri ve komplikasyonlar değerlendirildi. Hastaların klinik değerlendirmesi Olerud ve Molander skoru kullanılarak ve ayak bileği eklem hareket açıklı̆̆ ölçülerek yapıldı.

Bulgular: Otuz beş hastanın tamamında kaynama sağlandı. Ortalama kaynama süresi $16.5 \pm 2.8$ hafta (dağılım 12-24 hafta) ve ortalama Olerud ve Molander skoru $88 \pm 8.24$ idi. Bir hastada varus deformitesi, iki hastada valgus deformitesi ve bir hastada rotasyon deformitesi saptand. Üç hastada (\%9) yüzeyel enfeksiyon saptand1. Hiçbir hastada derin enfeksiyon saptanmadı.

Sonuç: İntramedüller çivi uygulaması basit intraartiküler distal tibia kırıkları için kontrendike değildir. Bu kırıklarda gerektiğinde ilave perkütan vida ile birlikte tekniğine uygun olarak yapılan intramedüller çivi uygulaması yüksek kaynama oranları, yüksek fonksiyonel sonuçlar ve düşük komplikasyon oranları ile başarılı bir tedavi seçeneğidir.

Anahtar sözcükler: Kırık sabitlenmesi; intraartiküler kırıklar; intramedüller; tibia kırıkları.

- Received: January 12, 2016 Accepted: March 24, 2016

- Correspondence: Ozan Beytemür, MD. Bağcılar Eğitim ve Araștırma Hastanesi Ortopedi ve Travmatoloji Kliniği, 34200 Bağcılar, İstanbul, Turkey. Tel: +90 530 - 8200992 Fax: +90 212 - 4404242 e-mail: beytemur@yahoo.com 
The ideal treatment method for distal tibial fractures remains controversial. Treatment options include conservative methods, plate and screw systems, intramedullary nails (IMNs), and external fixators. Each method has its own advantages and disadvantages. ${ }^{[1-7]}$ Conservative methods of treatment are often not chosen today due to the requirement of long-term immobilization of the knee and ankle joints, the difficulty of these treatments, and the length of treatment time. ${ }^{[3,8]}$ Although the fixing method with plate has the advantage of providing better mechanical support, there are publications reporting more complaints with this method, such as soft tissue problems and implant irritation. ${ }^{[9-12]}$ In the intramedullary nailing method, although soft tissue problems and complaints such as irritation connected to the implant are less frequent, mechanical problems and symptoms such as anterior knee pain are reported more frequently. ${ }^{[10,13]}$ But there are also some literature information which states that intramedullary fixation is stiffer. ${ }^{[14]}$ Although treatment of distal tibial fractures that do not extend to the ankle joint is controversial, the general procedure for distal tibial fractures extending to the ankle joint is anatomical reduction with osteosynthesis by plate. There are very few publications in the literature regarding the use of nails for intra-articular distal tibial fractures. ${ }^{[1,4]}$

In this retrospective study, we aimed to evaluate the functional and radiographic results and treatment complications of AO/OTA (Arbeitsgemeinschaft fur Osteosynthesefragen/Orthopaedic Trauma Association) type $43 \mathrm{C} 1$ and $\mathrm{C} 2$ fractures treated with intramedullary nailing.

\section{PATIENTS AND METHODS}

All distal tibial fractures treated at Bağcllar Training and Research Hospital between January 2009 and December 2014 were retrospectively evaluated. Simple, nondisplaced intra-articular extended fractures treated with IMN with at least one year of follow-up were included in the study. Other treatment methods except IMN (plate osteosynthesis, external fixator, etc.), displaced, and comminuted intra-articular distal tibial fractures were excluded.

Forty-one patients with AO/OTA type $43 \mathrm{C} 1$ or $\mathrm{C} 2$ tibial fractures extending to the ankle joint with at least one year of follow-up were assessed. Six patients could not be reached during the follow-up. As a result, 35 patients with AO/OTA type $43 \mathrm{C} 1$ or $\mathrm{C} 2$ fractures (26 males, 9 females; mean age $39.8 \pm 16.9$ years; range 19 to 82 years) were included. The ankle joints of all patients were evaluated with computed tomography. Early irrigation and debridement, antibiotherapy and skeletal traction were applied for open fractured patients. After ensuring that the wound was clean and uncomplicated, permanent surgery was applied. Firstly, ankle joints were assessed by fluoroscopy during surgery treatment. Later, temporary percutaneous Kirschner (K)-wires or interfragmentary screws perpendicular to the fracture site were inserted by the preoperative computed tomography and perioperative fluoroscopic determination. In all patients, these screws and K-wires were inserted percutaneously. Syndesmosis space was evaluated in the presence of the fibula fractures by mortis view under fluoroscopy. Surgical treatment for fibula fracture was not applied to the patients without syndesmosis injury. Patients with syndesmosis injury were firstly fixed with fibular plate before tibial nailing. Medial parapatellar approach was used in all patients for IMN application. Guide wire was aimed to be inserted at the center of the coronal and sagittal plane of distal tibia at anteroposterior and lateral views. Appropriate thickness and length of IMN were determined with limited reaming avoiding excessive reaming. Three distal locking screws were applied with sufficient distal distance and two distal locking screws were applied for less distal distances. Polar screws were not needed in any patients. Weight bearing was prohibited for six weeks postoperatively for all patients. Partial weight bearing was permitted after six weeks. After $10^{\text {th }}$ week, full load bearing was permitted when at least one cortex callus was seen radiologically. The study protocol was approved by the Bağcılar Training and Research Hospital Ethics Committee (2015-370). A written informed consent was obtained from each patient. The study was conducted in accordance with the principles of the Declaration of Helsinki.

The demographic characteristics of the patients (age, sex, mechanism of injury, site of injury, additional presence of fractures, whether the fractures were open or not, history of smoking or diabetes) were evaluated. In the postoperative evaluation, mean follow-up period, mean time to union, union status, infection status, and malunion were evaluated. In the evaluation of malunion, the presence of distal tibial varus-valgus or procurvatum-recurvatum deformities were evaluated radiologically. Rotational deformity was evaluated clinically. The injured limb was compared with the healthy limb by tibial tubercle, tibial crest, and ankle midpoint. Clinically and radiologically, above five degrees of deformity in any plane was evaluated as malunion. ${ }^{[1,2]}$ The number of screws applied to the distal tibial nail and the number of interfragmentary screws out of nail applied to the tibia were evaluated. Patients were clinically 
evaluated using the Olerud and Molander score and by measuring the ankle joint range of motion.

\section{Statistical analysis}

IBM SPSS version 22.0 software (IBM Corporation, Armonk, NY, USA) was used for statistical analysis. The mean, standard deviation, median minimum, median maximum, frequency, and ratio values were used for data descriptive statistics. The distribution of the variables was measured using the KolmogorovSmirnov test. In the analysis of quantitative data, the Mann-Whitney U test was used. In correlation analysis, Spearman correlation analysis was used. A $p$ value of $<0.05$ was considered as statistically significant.

\section{RESULTS}

Demographic characteristics of the patients are shown in Table I. Of the patients, the mechanism of injury was a fall in $23(66 \%)$, traffic accident in $10(29 \%)$, and sports injury in two (6\%). Fracture type was AO/OTA type $43 \mathrm{C} 1$ in 20 patients $(57 \%)$ and AO/OTA type $43 \mathrm{C} 2$ in 15 patients $(43 \%)$. Five patients $(14 \%)$ had type 1 and six patients $(17 \%)$ had type 2 open fractures according to the Gustilo and Anderson classification. Thirtythree patients $(94 \%)$ had fibula fractures. Fibular fixation was applied to four patients (11\%) with syndesmosis injury (Table I).

Two interfragmentary screws out of nail were applied in 10 patients (29\%) and one interfragmentary

TABLE

Characteristics of patients

\begin{tabular}{|c|c|c|c|c|c|}
\hline & $\mathrm{n}$ & $\%$ & Mean $\pm S D$ & Min.-Max. & Median \\
\hline Age (year) & & & $39.8 \pm 16.9$ & $19-82$ & 40 \\
\hline \multicolumn{6}{|l|}{ Gender } \\
\hline Female & 9 & 26 & & & \\
\hline Male & 26 & 74 & & & \\
\hline \multicolumn{6}{|l|}{ Side } \\
\hline Right & 24 & 69 & & & \\
\hline Left & 11 & 31 & & & \\
\hline \multicolumn{6}{|l|}{ Trauma mechanism } \\
\hline Falling & 23 & 66 & & & \\
\hline Sport injury & 2 & 6 & & & \\
\hline Traffic accident & 10 & 29 & & & \\
\hline \multicolumn{6}{|c|}{ Fracture type (AO/OTA classification) } \\
\hline $\mathrm{C} 1$ & 20 & 57 & & & \\
\hline $\mathrm{C} 2$ & 15 & 43 & & & \\
\hline \multicolumn{6}{|c|}{$\begin{array}{l}\text { Open fracture type } \\
\text { (Gustilo Anderson classification) }\end{array}$} \\
\hline 0 & 24 & 69 & & & \\
\hline 1 & 5 & 14 & & & \\
\hline 2 & 6 & 17 & & & \\
\hline \multicolumn{6}{|l|}{ Smoking } \\
\hline Yes & 8 & 23 & & & \\
\hline No & 27 & 77 & & & \\
\hline \multicolumn{6}{|c|}{ Diabetes mellitus history } \\
\hline Yes & 2 & 6 & & & \\
\hline No & 33 & 94 & & & \\
\hline \multicolumn{6}{|l|}{ Fibula Fx } \\
\hline Yes & 33 & 94 & & & \\
\hline No & 2 & 6 & & & \\
\hline \multicolumn{6}{|l|}{ Polytrauma } \\
\hline Yes & 4 & 11 & & & \\
\hline No & 31 & 89 & & & \\
\hline
\end{tabular}

SD: Standard deviation; Min.: Minimum; Max.: Maximum; AO/OTA: Arbeitsgemeinschaft fur Osteosynthesefragen/Orthopaedic Trauma Association. 
TABLE II

\begin{tabular}{|c|c|c|c|}
\hline \multicolumn{4}{|c|}{ Results $(n=35)$} \\
\hline & $\mathrm{n}$ & $\%$ & Mean $\pm S D$ \\
\hline Follow-up (months) & & & $31.9 \pm 9.8$ \\
\hline Union time (weeks) & & & $16.5 \pm 2.8$ \\
\hline Olerud-Molander score & & & $88 \pm 8.2$ \\
\hline Varus malalignment (degrees) & & & $0.6 \pm 1.4$ \\
\hline Valgus malalignment (degrees) & & & $1.9 \pm 1.7$ \\
\hline Recurvatum malalignment (degrees) & & & $0.3 \pm 0.8$ \\
\hline Procurvatum malalignment (degrees) & & & $0.2 \pm 0.6$ \\
\hline \multicolumn{4}{|l|}{ Rotation } \\
\hline No & 34 & 97 & \\
\hline Yes & 1 & 3 & \\
\hline Ankle dorsiflexion (degrees) & & & $25.9 \pm 4.6$ \\
\hline Ankle plantar flexion (degrees) & & & $39.4 \pm 5.9$ \\
\hline
\end{tabular}

SD: Standard deviation

screw out of nail was applied in 17 patients (49\%). Eight patients $(23 \%)$ were not applied any external screws. Inside the distal nail, three screws were applied in 18 patients $(51 \%)$ and two screws were applied in 17 patients (49\%). No complications were observed during IMN application.

Mean follow-up time was $31.9 \pm 9.8$ months (range: 13 to 50 months). Results are shown in Table II. Union was achieved in all 35 patients (100\%) (Figure 1 and 2). Mean union time was $16.5 \pm 2.8$ weeks (range 12 to 24 weeks). A statistically significant difference between the AO/OTA classification and fracture healing time was detected $(\mathrm{p}<0.05)$ (Figure 3, Table III). Healing time was significantly shorter in the $\mathrm{C} 1$ fracture type. No relationships between age, sex, wound status, smoking status, history of infection, number of screws applied to fracture or union time were observed $(\mathrm{p}>0.05)$. Four patients $(12 \%)$ had malunion. Varus deformity was detected in one patient, valgus deformity was detected in two patients, and rotation deformity was detected in one patient. Additional interventions were not applied due to absence of clinical symptoms and complaints. Five degrees of rotation were detected in one patient (3\%). Mean malunion and ankle range of motion degrees are shown in Table II.

Mean Olerud and Molander score was $88 \pm 8.24$ in functional results. A significant correlation between Olerud and Molander score and AO/OTA classification was detected. Olerud and Molander
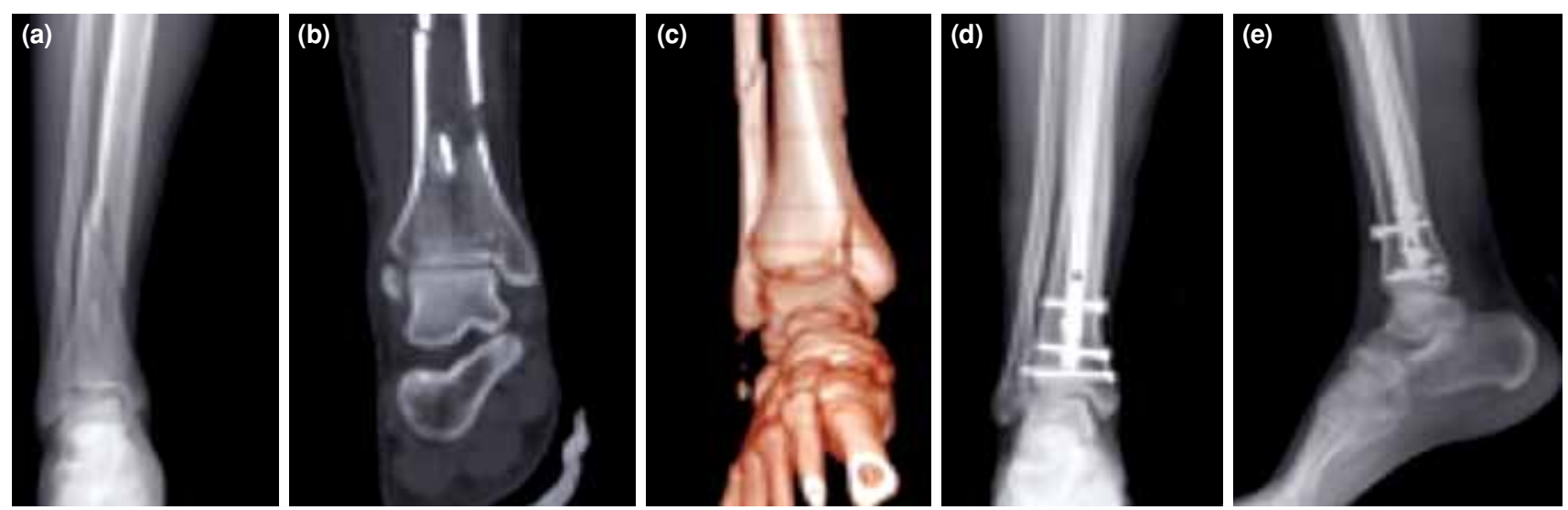

Figure 1. Twenty-two-year-old male with AO/OTA type 43C2 tibia fracture. (a) Preoperative anteroposterior X-ray, (b) preoperative lateral X-ray, (c) preoperative three-dimensional computed tomography, (d) postoperative anteroposterior $\mathrm{X}$-ray at $28^{\text {th }}$ month, (e) postoperative lateral X-ray at $28^{\text {th }}$ month. 

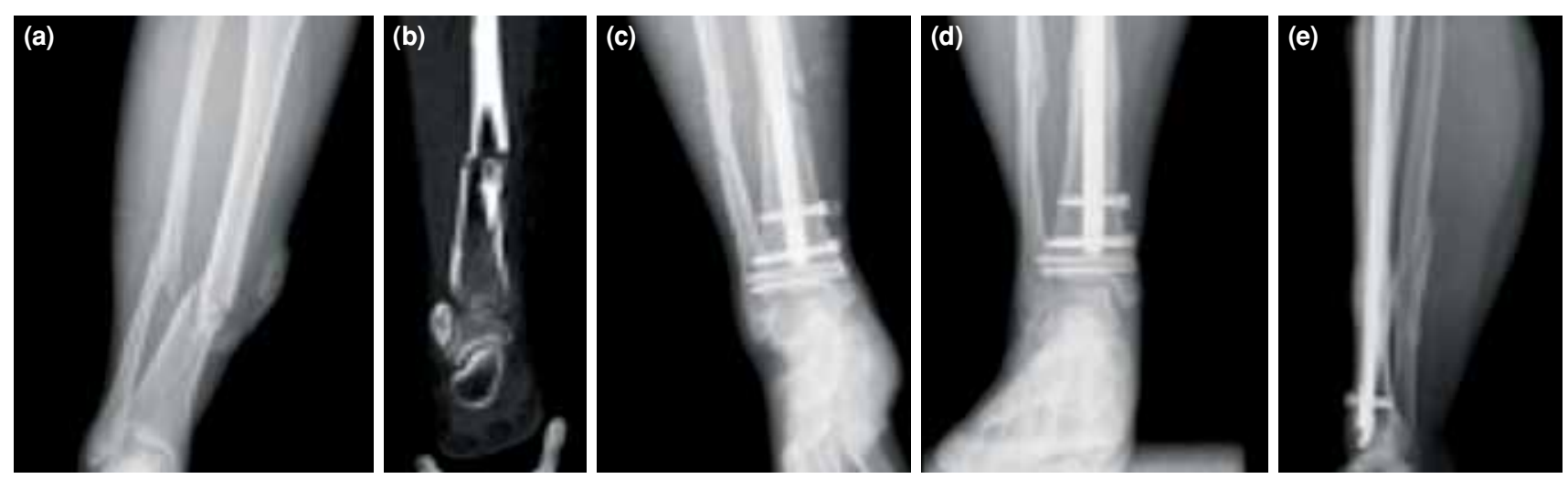

Figure 2. Thirty-eight-year-old female with AO/OTA type $43 \mathrm{C} 2$ tibia fracture. (a) Preoperative anteroposterior $\mathrm{X}$-ray, (b) preoperative lateral X-ray, (c) preoperative computed tomography, (d) postoperative anteroposterior X-ray at $13^{\text {th }}$ month, (e) postoperative lateral $X$-ray at $13^{\text {th }}$ month.

score was significantly higher in the $\mathrm{C} 1$ fracture type $(\mathrm{p}<0.05)$ (Figure 3$)$. The relationships between age, sex, wound status, smoking status, history of infection, and the number of screws and the Olerud and Molander score were not significant ( $\mathrm{p}>0.05)$.

There were some complications: superficial infection was detected in three patients $(9 \%)$ who were treated with oral antibiotics and wound dressings. Deep infection was not observed in any patient. The implant was removed in one patient due to implant irritation.

\section{DISCUSSION}

Although intramedullary nailing of tibia shaft fractures is the gold standard, treatment becomes controversial as the fracture extends distally. ${ }^{[1-4]}$ Intramedullary nailing and fixation with plate and screws are the most preferred methods of treatment for extra-articular distal tibia fractures. Both treatment methods have advantages and disadvantages..$^{[5-15]}$ One of the major findings of our study is the significantly higher rate of valgus malunion. This situation may be due to technical problems during the implementation of IMN, or due to the small number of fibular fixation in our study.

The tight fit of intramedullary nails provides a good fixation of shaft fractures. However, biomechanical support of intramedullary nails is reduced in the distal metaphyseal region, where the medulla widens.

The most important factor of the decrease in the mechanical support is the very few contacts between the cortex and the implant. ${ }^{[9]}$ In order to increase the mechanical strength, intramedullary nail options providing three distal screws in different configurations are available. Nork et al..$^{[3]}$ determined that application of three distal screws provided better

TABLE III

Relationship of Olerud and Molander score and union time between fracture type and Kruskal-Wallis / Mann-Whitney U tests

\begin{tabular}{|c|c|c|c|c|}
\hline & \multicolumn{3}{|c|}{ Olerud-Molander score } & \multirow[b]{2}{*}{$p$} \\
\hline & Mean $\pm S D$ & Min.-Max. & Median & \\
\hline \multicolumn{5}{|c|}{ Fracture type } \\
\hline $\mathrm{C} 1$ & $90.5 \pm 7.9$ & $70-100$ & 90 & \multirow{2}{*}{0.020} \\
\hline \multirow[t]{3}{*}{$\mathrm{C} 2$} & $84.7 \pm 7.7$ & $75-100$ & 85 & \\
\hline & \multicolumn{3}{|c|}{ Union time (week) } & \multirow[b]{2}{*}{$p$} \\
\hline & Mean $\pm S D$ & Min.-Max. & Median & \\
\hline \multicolumn{5}{|c|}{ Fracture type } \\
\hline $\mathrm{C} 1$ & $15.6 \pm 2.0$ & $12-20$ & 16 & \multirow[t]{2}{*}{0.045} \\
\hline $\mathrm{C} 2$ & $17.7 \pm 3.3$ & $12-24$ & 18 & \\
\hline
\end{tabular}

SD: Standard deviation; Min.: Minimum; Max.: Maximum. 

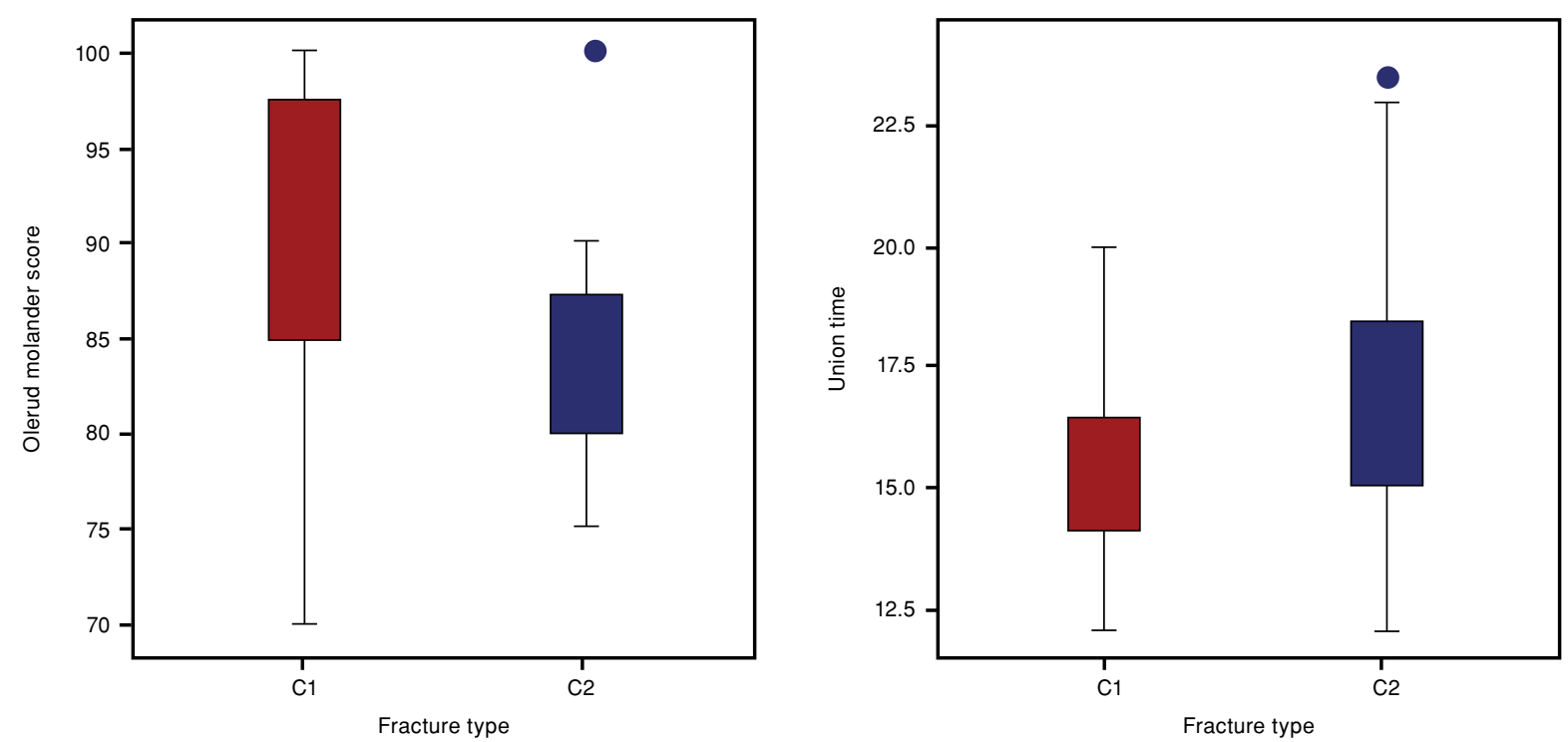

Figure 3. The relationship AO/OTA classification between Olerud Molander score and fracture healing time.

alignment than two screws in distal tibia fractures. We performed three distal screws in 18 patients with sufficient distance. However, two screws were applied for patients without sufficient distance.

In addition, one of the most noticeable problems of the intramedullary nailing technique is the malalignment of the tibia. During surgery, the guide wire must be carefully placed through the center of the coronal and sagittal planes of the ankle. ${ }^{[2]}$ Fixation of the fibula in distal tibial fractures is also a controversial topic. Egol et al. ${ }^{[16]}$ found a late malalignment rate of $4 \%$ in distal tibial fractures treated with fibular fixation and of $13 \%$ in distal tibial fractures treated without fibular fixation. In contrast, Vallier et al. ${ }^{[13]}$ found a higher rate of non-union with fibular fixation. The most important indication for fibular fixation is syndesmosis injury. If syndesmosis injury is diagnosed, fixation is absolutely necessary. ${ }^{[10,16]}$ In four of our patients, fibula fixation was performed because of syndesmosis injuries.

Another important point is to ensure absolute anatomic reduction of the articular line if the fracture extends to the joint line. The most recommended method is open anatomical reduction and plate fixation with screws. ${ }^{[4]}$ The intra-articular distal tibia fractures that we operated on were typically nondisplaced or minimally displaced.

According to the AO/OTA classification, type $43 \mathrm{C} 1$ and $\mathrm{C} 2$ patients were included in the study. Fragmented and multifragmented intra-articular fractures were not included. Our standard practice in these fractures is usually open reduction internal fixation with plate and screws or Ilizarov-type circular external fixations.

The intramedullary nailing method for AO/OTA type $\mathrm{C} 1$ and $\mathrm{C} 2$ fractures is less preferred because displacement of the intra-articular fracture fragments is seen more frequently during the application of nails when using this technique. ${ }^{[1-4]}$ We primarily fixed intraarticular fragments with temporary percutaneous K-wires or screws to avoid these complications before intramedullary nailing. Intra-articular fragment displacement did not occur in any of our patients.

One of the key reasons for choosing intramedullary nailing is the slight additional soft tissue damage and low incidence of symptoms such as implant irritation. ${ }^{[10-17]}$ Marcus et al. ${ }^{[1]}$ detected $1 \%$ superficial infection and $2 \%$ deep infection in 23 intra-articular extending tibia fractures treated with IMN. Katsenis et al. $^{[2]}$ never encountered infection in 50 patients treated with IMN. In our study, we found superficial infection in three patients (9\%), a finding consistent with the literature. Deep infection was not detected in any patient, which was also consistent with the literature.

Soft tissue problems and infection rates were significantly higher in distal tibial fractures treated with open reduction and plate osteosynthesis than IMN in the comparative studies. ${ }^{[10]}$

Today, the plate and screws method for distal tibial fractures has taken an important place. This is primarily because newly developed minimally 
invasive low-profile plate systems are more practical and biological than the conventional plate system. Although wound complications and infection problems are more often detected in the literature with plate fixation, several studies have found no difference. ${ }^{[13]}$

The most important advantage of the plate and screws application is stronger biomechanical stability. The new generation intramedullary nail types increase biomechanical strength by allowing for application of an increased number of nails and distal screws. ${ }^{[10]}$ In our patients, we did not detect any biomechanical problems.

The most important disadvantage of intramedullary nails is anterior knee pain. Quite different ratios regarding anterior knee pain have been reported in the literature. ${ }^{[1,17]}$ Although several factors have already been blamed for anterior knee pain, the main reason is still not clear. However, Weil et al. ${ }^{[17]}$ reported a 19\% rate of anterior knee pain with the parapatellar approach. We applied the parapatellar approach to all of our patients and found a $22 \%$ rate of anterior knee pain $(n=8)$.

Limitations of our study include the small sample size, the retrospective study design, and the lack of comparison groups.

In conclusion, intramedullary nailing is not contraindicated for distal tibial fractures with nondisplaced, intra-articular fragments, as reported in the literature. ${ }^{[1,4]}$ Intramedullary nailing in accordance with the surgical technique, with additional percutaneous screws if necessary, is a successful treatment option for AO/OTA type 43C1 and $\mathrm{C} 2$ fractures with high fracture union rates, high functional results, and low complication rates.

\section{Declaration of conflicting interests}

The authors declared no conflicts of interest with respect to the authorship and/or publication of this article.

\section{Funding}

The authors received no financial support for the research and/or authorship of this article.

\section{REFERENCES}

1. Marcus MS, Yoon RS, Langford J, Kubiak EN, Morris AJ, Koval $\mathrm{KJ}$, et al. Is there a role for intramedullary nails in the treatment of simple pilon fractures? Rationale and preliminary results. Injury 2013;44:1107-11.

2. Katsenis DL, Begkas D, Spiliopoulos G, Stamoulis D, Pogiatzis K. The results of closed intramedullary nailing for intra-articular distal tibial fractures. J Orthop Trauma
2014;28:108-13.

3. Nork SE, Schwartz AK, Agel J, Holt SK, Schrick JL, Winquist RA. Intramedullary nailing of distal metaphyseal tibial fractures. J Bone Joint Surg Am 2005;87:1213-21.

4. Robinson CM, McLauchlan GJ, McLean IP, Court-Brown $\mathrm{CM}$. Distal metaphyseal fractures of the tibia with minimal involvement of the ankle. Classification and treatment by locked intramedullary nailing. J Bone Joint Surg $\mathrm{Br}$ 1995;77:781-7.

5. Aldemir C, Doğan A, İnci F, Sertkaya Ö, Duygun F. Distal locking techniques without fluoroscopy in intramedullar nailing. [Article in Turkish] Eklem Hastalik Cerrahisi 2014;25:64-9.

6. Karakaşli A, Satoğlu İS, Havitçioğlu H. A new intramedullary sustained dynamic compression nail for the treatment of long bone fractures: a biomechanical study. Eklem Hastalik Cerrahisi 2015;26:64-71.

7. Konrath G, Moed BR, Watson JT, Kaneshiro S, Karges DE, Cramer KE. Intramedullary nailing of unstable diaphyseal fractures of the tibia with distal intraarticular involvement. J Orthop Trauma 1997;11:200-5.

8. Sarmiento A, Gersten LM, Sobol PA, Shankwiler JA, Vangsness CT. Tibial shaft fractures treated with functional braces. Experience with 780 fractures. J Bone Joint Surg Br 1989;71:602-9.

9. Berlusconi M, Busnelli L, Chiodini F, Portinaro N. To fix or not to fix? The role of fibular fixation in distal shaft fractures of the leg. Injury 2014;45:408-11.

10. Casstevens C, Le T, Archdeacon MT, Wyrick JD. Management of extra-articular fractures of the distal tibia: intramedullary nailing versus plate fixation. J Am Acad Orthop Surg 2012;20:675-83.

11. Li Y, Jiang X, Guo Q, Zhu L, Ye T, Chen A. Treatment of distal tibial shaft fractures by three different surgical methods: a randomized, prospective study. Int Orthop 2014;38:1261-7.

12. Iqbal HJ, Pidikiti P. Treatment of distal tibia metaphyseal fractures; plating versus intramedullary nailing: a systematic review of recent evidence. Foot Ankle Surg 2013;19:143-7.

13. Vallier HA, Le TT, Bedi A. Radiographic and clinical comparisons of distal tibia shaft fractures $(4$ to $11 \mathrm{~cm}$ proximal to the plafond): plating versus intramedullary nailing. J Orthop Trauma 2008;22:307-11.

14. Nourisa J, Rouhi G. Biomechanical evaluation of intramedullary nail and bone plate for the fixation of distal metaphyseal fractures. J Mech Behav Biomed Mater 2016;56:34-44.

15. Bahari S, Lenehan B, Khan H, McElwain JP. Minimally invasive percutaneous plate fixation of distal tibia fractures. Acta Orthop Belg 2007;73:635-40.

16. Egol KA, Weisz R, Hiebert R, Tejwani NC, Koval KJ, Sanders RW. Does fibular plating improve alignment after intramedullary nailing of distal metaphyseal tibia fractures? J Orthop Trauma 2006;20:94-103.

17. Weil YA, Gardner MJ, Boraiah S, Helfet DL, Lorich DG. Anterior knee pain following the lateral parapatellar approach for tibial nailing. Arch Orthop Trauma Surg 2009;129:773-7. 